\title{
Scouting for Insects, Use of Thresholds and Conservation of Beneficial Insects on Tomatoes ${ }^{1}$
}

\author{
David J. Schuster ${ }^{2}$ \\ Integrated pest management (IPM) can be \\ defined as the utilization of all available tactics for \\ managing pests such that economic loss is avoided \\ and environmental impact minimized. The \\ cornerstone of IPM is a knowledge of the pests \\ attacking a crop and an understanding of the \\ relationship of density of those pests to crop damage. \\ Therefore, every IPM program is dependent upon \\ periodic scouting to ascertain pest density and upon \\ establishment of densities when treatment is \\ warranted, i.e. thresholds. Although thresholds based \\ upon the economics of the crop and upon the cost of \\ treatment have been developed for some pests of \\ vegetables, these "economic" thresholds generally \\ have not been used because of the variability and \\ unpredictability of the ultimate market value of \\ winter vegetables. Therefore, action thresholds have \\ been utilized. Action thresholds can be defined as \\ those levels of pest density or damage that result in \\ consistently (statistically) measurable losses in yield \\ quantity or quality. What follows is a description of \\ the rationale of scouting methodology, action \\ thresholds, and pesticide selection criteria for \\ tomatoes.
}

\section{Scouting Methodology}

Scouting methods should not only take into account the relative density and distribution of pests but also the stage of growth of the plant. In tomato the area of each field is measured and two acre grids are established. A sample is taken from 6 contiguous plants in each grid to ensure that every area of the field is sampled. For whiteflies 10 contiguous plants are sampled because whitefly populations tend to be more clumped than other pests. The numbers of whiteflies, aphids, lepidopterous eggs, and living and dead leafminer larvae are counted either on the whole plant or on the terminal leaflet(s) of the $3^{\text {rd }}$ or $7^{\text {th }}$ leaf from the top of the main stem or lateral branches, depending upon crop phenology (Table 1). This procedure takes into account that the distribution of leafminer larvae and whitefly nymphs on leaves moves up the plant as it grows, and that most larvae and nymphs occur on leaves 6 to 10, counting from the top. Counting from the top ensures that the leaf selected for sampling is consistently of the same age, regardless of plant age or stem status (i.e. main, lateral or even sub-lateral stems), and consistently in the region of the plant where most larvae or nymphs occur.

1. This is document ENY685, one in a series of the Entomology Department, Florida Cooperative Extension Service, Insitute of Food and Agricultural Sciences, University of Florida. Please visit the EDIS Website at http://edis.ifas.ufl.edu.

2. David J. Schuster, professor, Gulf Coast Research and Education Center, Bradenton, Florida Cooperative Extension Service, Institute of Food and Agricultural Sciences, University of Florida, Gainesville, FL 32611.

The Institute of Food and Agricultural Sciences is an equal opportunity/affirmative action employer authorized to provide research, educational information and other services only to individuals and institutions that function without regard to race, color, sex, age, handicap, or national origin. For information on obtaining other extension publications, contact your county Cooperative Extension Service office. Florida Cooperative Extension Service/Institute of Food and Agricultural Sciences/University of Florida/Christine Taylor Waddill, Dean. 
To determine whether leafminer larvae are dead or alive, leaflets are removed from the plant, held up to the sun and examined with a hand lens. Living larvae are a pale yellow and flush with the end of the mine. The back and forth feeding movements of the mouth hooks is readily visible, although movement may cease momentarily when larvae are disturbed or may cease for an extended time when larvae are molting. Dead larvae do not show mouth hook movement and are usually discolored and removed from the ends of mines. Determining whether whitefly nymphs are alive or dead is more difficult and subjective. Living nymphs are usually clear and contain paired yellow mycetomes, whereas dead nymphs are usually discolored and contain orange mycetomes. They may appeared collapsed, especially if fed upon by predators.

Yellow sticky traps can be used for estimating relative densities of leafminer and whitefly adults but are most useful in determining changes in adult densities over time. Whitefly adults may be sampled by carefully turning over the $3^{\text {rd }}$ leaf from the top and counting the whiteflies present. Morning sampling is best because whitefly adults become more easily disturbed and, hence, put to flight as the temperature increases during the day. Leafminer adults occur on the upper leaf surfaces and are most abundant on the upper third of the plant. They can be readily observed without disturbing the plant.

Whole plants are examined for noctuid larvae and true bugs, with the focus of the former being recently damaged foliage. After fruit set, 10 fruit per site are examined for damage. Tomato pinworm larvae are counted either on the foliage of whole plants or on one leaf selected from the lower canopy of each plant. To sample thrips, 15 flowers are selected and the numbers of thrips escaping after exhaling on the flowers and tapping them on the palm or a piece of paper are counted.

\section{Action Thresholds}

The action thresholds for tomato also take into account crop phenology (Table 1). The thresholds for aphids, whiteflies and thrips are applied to inhibit population buildup or fruit damage or to maintain fruit quality, but not to avoid virus transmission. Prior to the appearance of the western flower thrips and the virus it transmits, tomato spotted wilt, the primary concern was bloom abscission. The threshold for "halo spotting" of fruit, caused by oviposition of the western flower thrips, is one-third of the flowers infested. The threshold of 5 nymphs/10 leaflets for the silverleaf whitefly was developed to time applications of the insect growth regulators buprofezin (Courier) and pyriproxyfen (Knack) in order to avoid the irregular ripening fruit disorder caused by feeding of nymphs. In general, applications of insecticides to control aphids or thrips have not been successful in reducing incidence of the viruses these insects transmit. However, insecticide applications have reduced the in-field spread of insect-transmitted viruses, especially those vectored by whiteflies.

\section{Conservation of Natural Enemies}

At least 14 species of hymenopterous (wasp) parasites attack Liriomyza spp. leafminers on nonsprayed tomatoes in Florida; however, four parasite species predominate: Diglyphus intermedius (Girault), D. begini (Ashmead), Neochrysocharis (=Chrysonotomyia) punctiventris (Crawford) and Opius dissitus Muesebeck. Up to $90 \%$ parasitism in nonsprayed tomatoes has been observed in Florida. In commercial tomatoes using selective insecticides to kill leafminers and conserve parasites, parasitism can reach $100 \%$. The tomato pinworm has been shown to be attacked by a number of parasites in Florida including Apanteles dignus Muesebeck, A. scutellaris Muesebeck, Temelucha spp., Sympiesis stigmatipennis Girault and Trichogramma pretiosum Riley. Parasitism in commercial fields can range from $40-60 \%$, with the higher rates occurring later in the crop. Egg parasitism ranges as high as $60-90 \%$, with the higher rates occurring at lower egg densities. The silverleaf whitefly is attacked by at least 15 species of parasites and 19 species of predators in Florida. A relatively small number of parasites predominate, with Encarsia pergandiella Howard, Eretmocerus sp., and Encarsia nigricephala Dozier being the most abundant. The minute pirate bug, Orius insidiosus (Say), and the lacewing, Ceraeochrysa cubana (Hagen), were among the most numerous predators. Parasitism of the whitefly on vegetables grown on a southwest Florida organic farm 
has reached up to $80 \%$ while combined parasitism and predation in nonsprayed weeds has resulted in up to $100 \%$ mortality.

The relative toxicity of selected pesticides to parasites of leafminers and the tomato pinworm and to parasites and predators of the silverleaf whitefly are shown in Tables 2 and 3. Some pesticides like methomyl are highly toxic to all lifestages of all natural enemies evaluated while others, like methamidophos, are highly toxic to some life stages of natural enemies but not all. Some insecticides like azadirachtin were moderately toxic to some life stages and relatively non-toxic to most others while others like Bacillus thuringiensis and cyromazine were relatively non-toxic to all life stages of all natural enemies evaluated. Therefore, it is important that the scouting program include not only an assessment of the pests present but also the natural enemies, including the specific life stage(s). If these guidelines are followed, conservation of natural enemies through the use of timed applications of selective insecticides for the above pests can not only be feasible but can be a reality.

\section{References}

Liu. T. X. and P. A. Stansly. 1996. Toxicological Effects of Selected Insecticides on Nephaspis oculatus (Col.: Coccinellidae), a Predator of Bemisia argentifolii (Hom.: Aleyrodidae). J. Appl. Entomol. 120:369-373.

Pernezny, K., D. Schuster, P. Stansly, G. Simone, V. Waddill, J. Funderburk, F. Johnson, R. Lentini and J Castner. 1996. Florida Tomato Scouting Guide with Insect and Disease Identification Keys. Univ. of Florida, IFAS, Florida Cooperative Extension Service, SP-22.

Pohronezny, K. and V. Waddill. 1978. Integrated Pest Management-Development of an Alternative Approach to Control Tomato Pests in Florida. Univ. of Florida, Ext. Plant Pathol. Rpt. No. 22, 7pp.

Pohronezny, K. L., J. Francis and V. Waddill. 1980. Tomato Pest Management Program-Guidelines for Scouts. Univ. of Florida, IFAS, Ext. Plant Pathol. Rpt No. 28, 10pp.
Pohronezny, K., V. H. Waddill, D. J. Schuster and R. M. Sonoda. 1986. Integrated Pest Management for Florida Tomatoes. Plant Dis. 70: 96-102.

Schuster, D. J. 1994. Life-stage Specific Toxicity of Insecticides to Parasitoids of Liriomyza trifolii (Burgess) (Diptera: Agromyzidae). Intl. J. Pest Mgmt. 40: 191-194.

Schuster, D. J. and K. Pohronezny. 1989. Practical Application of Pest Management on Tomatoes in Florida. Pages 275-288 in: S. K. Green [ed.], Tomato and Pepper Production in the Tropics, Proc. Intl. Symp. Integrated Management Practices. Asian Vegetable Res. and Dev. Ctr., Shanhua, Tainan, Taiwan.

Schuster, D. J. and P. A. Stansly. 2000. Response of Two Lacewing Species to Biorational and Broad-spectrum Insecticides. Phytoparasitica 28:297-304.

Schuster, D. J., R. T. Montgomery, D. L. Gibbs, G. A. Marlowe, Jr., J. P. Jones and A. J. Overman. 1980. The Tomato Pest Management Program in Manatee and Hillsborough Counties, 1978-1980. Proc. Florida State Hort. Soc. 93: 235-239.

Stansly, P. A. and T. X. Liu. 1996. Selectivity of Insecticides to Encarsia pergandiella (Hymenoptera: Aphelinidae), Endoparasitoid of Bemisia argentifolii (Homoptera: Aleyrodidae). Bull. Entomol. Res. 87:525-531.

Waddill, V. H. 1978. Contact Toxicity of Four Synthetic Pyrethroids and Methomyl to Some Adult Insect Parasites. Florida Entomol. 61: 27-30. 
Table 1. Sampling methods and action thresholds for management of arthropod pests of tomatoes in Florida.

\begin{tabular}{|c|c|c|c|}
\hline Arthropod pests & Crop phenology & Sampling method* & Threshold \\
\hline Aphids & $\begin{array}{l}0-2 \text { true leaves } \\
>2 \text { true leaves }\end{array}$ & $\begin{array}{l}\text { Whole plant inspection } \\
\text { Terminal } 3 \text { leaflets of } 3 \text { rd or } \\
\text { 7th leaf from top }\end{array}$ & 3-4/plant \\
\hline Armyworms, fruitworms & $\begin{array}{l}\text { Pre-bloom } \\
\text { Post-bloom }\end{array}$ & $\begin{array}{l}\text { Whole plant inspection } \\
\text { Whole plant inspection } \\
\text { Inspection of } 10 \text { fruit } \\
\text { Terminal } 3 \text { leaflets of } 3 \text { rd or } \\
7 \text { th leaf from the top }\end{array}$ & $\begin{array}{l}1 \text { larva/ } 6 \text { plants } \\
1 \text { egg or larva/sample }\end{array}$ \\
\hline Leafminers & $\begin{array}{l}0-2 \text { true leaves } \\
>2 \text { true leaves }\end{array}$ & $\begin{array}{l}\text { Whole plant inspection } \\
\text { Terminal } 3 \text { leaflets of } 3 \text { rd or } \\
\text { 7th leaf from top }\end{array}$ & $\begin{array}{l}1 \text { live larva/plant } \\
1 \text { live larva/3 terminal leaflets }\end{array}$ \\
\hline Loopers & $\begin{array}{l}\text { Season-long } \\
\text { Post-bloom }\end{array}$ & $\begin{array}{l}\text { Whole plant inspection } \\
\text { Inspection of } 10 \text { fruit }\end{array}$ & 1 larva/6 plants \\
\hline Spider mites & Season-long & $\begin{array}{l}\text { Terminal } 3 \text { leaflets of } 1 \text { leaf } \\
\text { from lower canopy }\end{array}$ & 10 mites/leaflet \\
\hline Thrips, Wester flower & Bloom & Exhaling on 15 flowers & $>0.33$ of flowers infested \\
\hline Thrips, other & Bloom & Exhaling on 15 flowers & $>5 /$ flower \\
\hline Tomato pinworm & $\begin{array}{l}0-7 \text { true leaves } \\
>7 \text { true leaves }\end{array}$ & $\begin{array}{l}\text { Whole plant inspection } \\
\text { One leaf from lower canopy }\end{array}$ & $\begin{array}{l}0.7 \text { larva/plant } \\
0.7 \text { larva/plant }\end{array}$ \\
\hline True bugs & Post-bloom & $\begin{array}{l}\text { Whole plant inspection } \\
\text { Inspection of } 10 \text { fruit }\end{array}$ & 1 nymph or adult/plant \\
\hline Whiteflies & $\begin{array}{l}0-3 \text { true leaves } \\
>3 \text { true leaves }\end{array}$ & $\begin{array}{l}\text { Whole plant inspection } \\
\text { Terminal leaflet of 3rd } \\
\text { (adults) or } 7 \text { th (nymphs or } \\
\text { pupae) leaf from the top }\end{array}$ & $\begin{array}{l}1 \text { adult/plant }{ }^{* *} \\
1 \text { adult/leaflet } \\
5 \text { nymphs } / 10 \text { leaflets }\end{array}$ \\
\hline \multicolumn{4}{|c|}{$\begin{array}{l}\text { * The method was applied to one six-plant sample per two acres. } \\
\text { **If the source of whiteflies is tomato, especially tomato infected with ToMoV or TYLCV, the thresholds would be lower. } \\
\text { Sources: Pohronezny and Waddill (1978); Schuster et al. (1980); Pohronezny et al. (1980); Pohronezny et al. (1986); } \\
\text { Schuster and Pohronezny (1989); Pernezny et al. (1996). }\end{array}$} \\
\hline
\end{tabular}

Table 2. Toxicity of field rates of insecticides utilized in Florida tomato production to parasites of the tomato pinworm, Keiferia lycopersicella, and Liriomyza spp. leafminers. *

\begin{tabular}{|c|c|c|c|c|}
\hline \multirow[t]{2}{*}{ Insecticide common name (Trade name) } & $\begin{array}{c}\text { Tomato } \\
\text { pinworm } \\
\text { parasite }\end{array}$ & \multicolumn{3}{|c|}{ Leafminer parasites } \\
\hline & Apanteles sp. & $\begin{array}{c}\text { Diglyphus } \\
\text { intermedius } \\
\end{array}$ & $\begin{array}{c}\text { Neochrysocharis } \\
\text { punctiventris }\end{array}$ & $\begin{array}{c}\text { Opius } \\
\text { bruneipes }\end{array}$ \\
\hline Abamectin (Agri-Mek) & ---- & $\begin{array}{c}++(\text { adults, pupae }) \\
+++(\text { larvae })\end{array}$ & $\begin{array}{c}\text { +(adults) } \\
++(\text { pupae }) \\
+++(\text { larvae })\end{array}$ & ---- \\
\hline Bacillus thuringiensis & ---- & + & + & --- \\
\hline Cyromazine (Trigard) & ---- & + & + & ---- \\
\hline
\end{tabular}


Table 2. Toxicity of field rates of insecticides utilized in Florida tomato production to parasites of the tomato pinworm, Keiferia lycopersicella, and Liriomyza spp. leafminers. *

\begin{tabular}{|c|c|c|c|c|}
\hline \multirow[t]{2}{*}{ Insecticide common name (Trade name) } & \multirow{2}{*}{$\begin{array}{c}\begin{array}{c}\text { Tomato } \\
\text { pinworm } \\
\text { parasite }\end{array} \\
\text { Apanteles sp. }\end{array}$} & \multicolumn{3}{|c|}{ Leafminer parasites } \\
\hline & & $\begin{array}{c}\text { Diglyphus } \\
\text { intermedius }\end{array}$ & $\begin{array}{c}\text { Neochrysocharis } \\
\text { punctiventris }\end{array}$ & $\begin{array}{c}\text { Opius } \\
\text { bruneipes }\end{array}$ \\
\hline Endosulfan (Thiodan & ---- & $\begin{array}{c}++(\text { pupae }) \\
+++(\text { adults, larvae })\end{array}$ & $\begin{array}{c}+++(\text { pupae }) \\
++++(\text { adults } \\
\text { larvae })\end{array}$ & + \\
\hline Fenvalerate (Pydrin) & + & $\begin{array}{c}++(\text { pupae }) \\
+++(\text { adults, larvae })\end{array}$ & $\begin{array}{c}++(\text { larvae, pupae }) \\
+++(\text { adults })\end{array}$ & --- \\
\hline Methamidophos (Monitor) & ---- & $\begin{array}{c}+++(\text { larvae }) \\
+ \text { (pupae }) \\
++++(\text { adults })\end{array}$ & $\begin{array}{c}++(\text { larvae, pupae }) \\
+++++(\text { adults })\end{array}$ & ---- \\
\hline Methomyl (Lannate) & ++++ & ++++ & ++++ & ++++ \\
\hline Permethrin (Ambush, Pounce) & ++++ & ++++ & ++++ & ++ \\
\hline $\begin{array}{l}{ }^{*} \text { Relative toxicity ranges }+=<25 \% ;++= \\
\text { Apanteles and Opius. A dashed line indic } \\
(1994) .\end{array}$ & $\begin{array}{l}<50 \% ;+++=5 \\
\text { the parasitoid }\end{array}$ & $\begin{array}{l}<75 \% \text {; and }++++>7 \\
\text { not evaluated. Sour }\end{array}$ & $\begin{array}{l}\text { Only adults evalu } \\
\text { : Waddill (1978); }\end{array}$ & $\begin{array}{l}\text { d for } \\
\text { ister, }\end{array}$ \\
\hline
\end{tabular}

Table 3. Toxicity of field rates of selected insecticides to natural enemies of Bemisia tabaci in the laboratory.

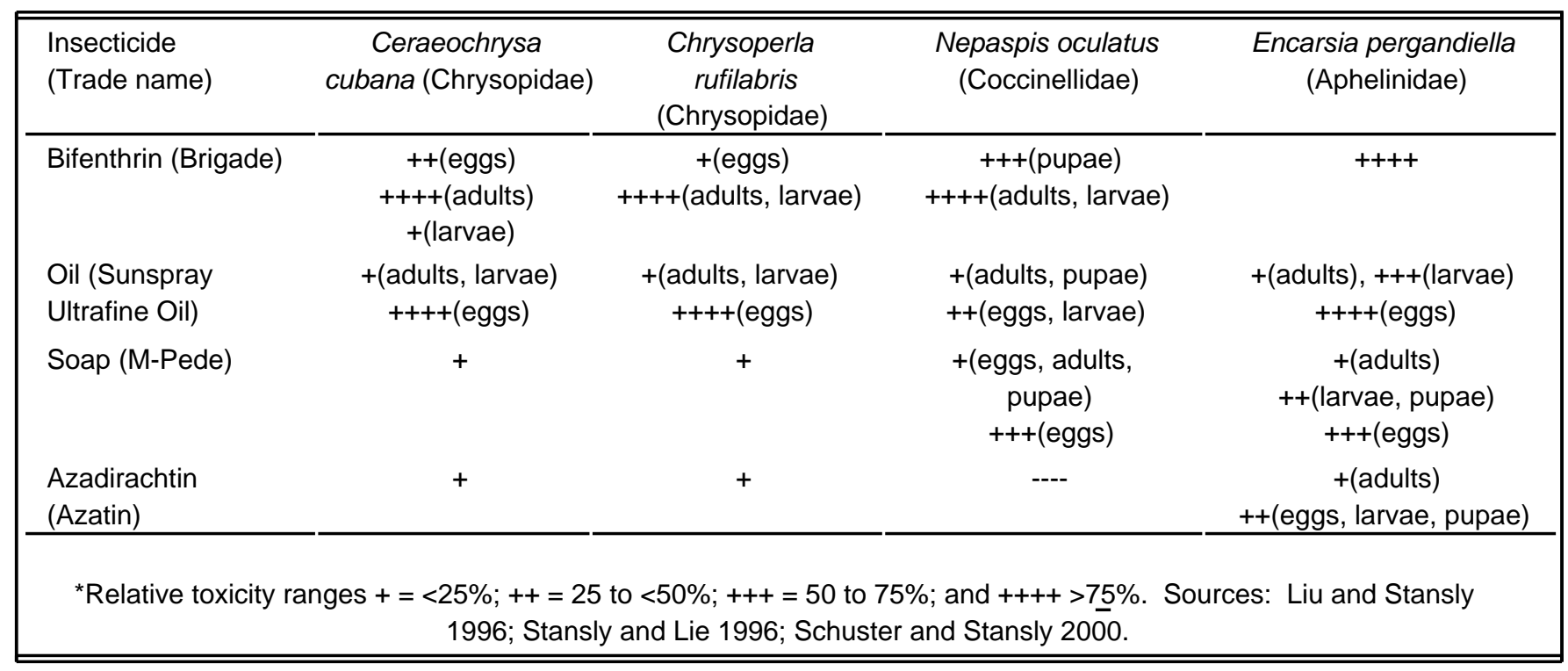

